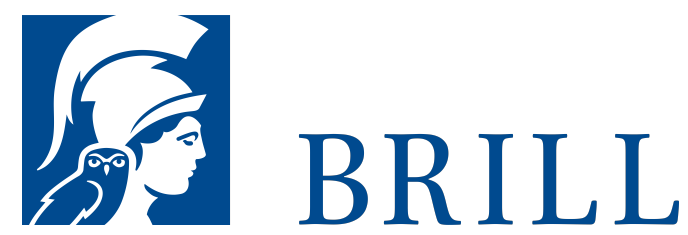

\title{
Reading the Bible across Contexts
}

Luke's Gospel, Socio-Economic Marginality, and Latin American Biblical Hermeneutics

Author: Esa J. Autero

In Reading the Bible Across Contexts Esa Autero offers a fresh perspective on Luke's poverty texts. In addition to an historical reading, he conducted an empirical investigation of two Latin American Bible reading groups - one poor and the other affluent - to shed light on Luke's poverty texts. The interaction between historical reading and present-day readings demonstrates the impact of socio-economic status on biblical hermeneutics and sheds new light on Luke's views on wealth and poverty. At the same time Esa Autero critically examines liberation theologian's claim that poor are privileged biblical interpreters.

\section{Readership}

All interested in wealth and poverty in Luke's Gospel, contextual hermeneutics, empirical hermeneutics, and Latin American biblical hermeneutics. Also, anyone concerned with Pentecostal hermeneutics in Latin America.

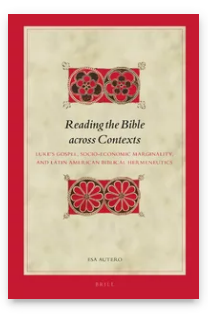

Pages: xiv, 418 pp.

Language: English

Subjects:

Biblical

Interpretations, Biblical Studies, New Testament \& Early Christian Writings,

Biblical Studies, Latin America, American

Studies, Comparative

Religion \&

Religious

Studies, Religious Studies, World Christianity, Theology and

World

Christianity

Publisher: Brill

Series:

Biblical

Interpretation Series, Volume:

145

E-Book (PDF)

Released online: 10 Jun 2016 
ISBN: $978-90-$

Esa J. Autero, Dr.Theol., (2014) University of Helsinki, Finland, is 04-32320-9

List price

USD $\$ 223.00$ the Dean of Faculty at South Florida Theological Seminary. His research and publications focus on the Gospels and contextual hermeneutics, including Ghosts, Women, and Evangelism ( $A$ Dialogue between Bolivia and Indonesia) (SBL Press, 2015).

For more information see brill.com

Hardback

Publication date:

16 Jun 2016

ISBN: $978-90-$

04-32319-3

List price

USSD \$223.00

Order information: Order online at brill.com +44330 3330049 | customerservices@brill.com Submission information: brill.com/authors

Titles published by Brill | Fink, Brill | mentis or Brill | Schöningh: +49(o)71 5413279216 | brill@brocom.de 